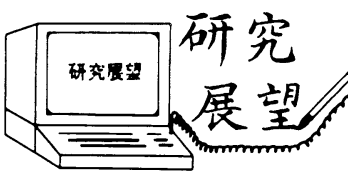

バイオメカニクス研究における倫理的配慮*

(ヒトに関わる研究について)
日本機械学会論文集 $(\mathrm{A}$ 編)

74 巻 737 号 $(2008-1)$

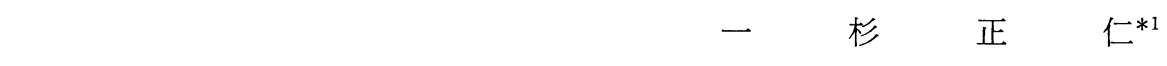

Ethical Problems in Biomechanical Research Involving Human Subjects

\author{
Masahito HITOSUGI*2 \\ ${ }^{* 2}$ Department of Legal Medicine, Dokkyo Medical University School of Medicine, \\ 880 Kitakobayashi, Mibu, Shimotsuga-gun, Tochigi, 321-0293 Japan
}

Key Words : Biomechanics, Bioethics, Medicine, Human, Medical Equipment, Medical and Welfare Assistance

1.はじめに

ヒトを対象とする研究やヒト由来の組織を用いる研 究では, 十分な倫理的配慮が必要である. 研究者各自 が十分な手続きを踏み, 社会的コンセンサスが得られ る方法で実践することが要求される。しかし一方で, 過度の用心深さから研究や調査などが停滞すること は，ヒトの健康増進や安全向上において好ましいこと ではない.

研究者は，みずからの研究領域において，既存する 法律に抵触せず，かつ，倫理的問題に十分配慮するこ とが要求される.わが国でも，研究者を補助するうえ で, 行政や学会などが倫理面に関する指針や規範を策 定してきた。したがって，研究者がこれらを遵守する ことで, 後述の多くのトラブルは回避することができ る.しかし，一切のトラブルに遭遇しないとは言い切 れない.すなわち, 法律や指針が網羅できないような 問題, 科学技術の進歩によって, かつて想定されなか った問題が発生することがある。ただし, 基本的原則 さえ身につけていれば，個々の研究者の応用力あるい は常識的な判断で解決できるであろう.

本稿では，特にヒトあるいはヒト由来試料を用いる バイオメカニクス研究に携わる研究者が, 知っておく べき倫理的原則について概説する.

\section{2. 生命倫理とバイオメカニクス研究}

生命倫理とは, 生命科学や医療に関連して生じる倫

\footnotetext{
* 原稿受付 2007 年 9 月 21 日.

*1 獨協医科大学法医学講座 (-321-0293 栃木県下都賀郡壬生 町北小林 880 ).

E-mail : hitosugi@dokkyomed.ac.jp
}

理的な問題について議論し，研究する学問である(1). 近年, 生命倫理に関する問題が浮上してきた背景には, 生命科学や医療技術の発展に伴って, 生命や医療に関 するさまざまな課題が提起されてきたことがある。生 命倫理の 4 原則として, 自律尊重, 無危害, 善行(仁 恵)，正義が挙げられる。しかし，この原則を機械的に 当てはめるだけでは, 医療や科学研究の現場で生じた 諸問題を解決できないことが多い.したがって, 個々 の問題に対しては，原則を柱として議論を重ねながら 解決していくことが重要である。

バイオメカニクスとは, 生体力学あるいは生体工学 と訳され, 生体機能に力学的原理を応用する科学であ る(2)(3). バイオメカニクスの研究分野は身体の運動機 能, 生体組織や材料の特性といった基礎的なものから, 医療器具や人工臓器の開発に至るまで多岐にわたる. そして, 理学, 工学, 生物学, 医学など多くの分野の研 究者が携わっている. 材料力学の研究では, 金属やプ ラスティックといった工業材料を用いた研究が主流で あった。しかし, バイオメカニクス研究では, 生体へ の応用を検討するために生体(Human volunteer), 七 トの死体 (Cadaver, Postmortem human subject: PMHS)，ヒト由来の組織，動物などを試料として用 いることがある.したがって，これらを用いる際には， 当然のことながら倫理的配慮が要求される.

\section{3. ヒトを対象とした研究の倫理}

適切なバイオメカニクス研究は, 科学的に妥当な計 画と十分な倫理的配慮のもとに実施されなければなら ない. 特に，ヒトを対象とする研究の歷史を考えるう えでは, 戦争中の人体実験を忘れてはならない. 1947 年, 第二次世界大戦中のナチスドイツの人体実験に関 
連して, 連合国によって戦争犯罪を裁く国際法廷が二 ユルンベルクで開かれた。そして, 被験者の人権尊重 を誓った「ニュルンベルク綱領」が採択され，これが インフォームド・コンセント(十分な説明を受け，理 解して同意すること)の基礎となった。1964 年に世界 医師会は，ヒトを対象とする医学研究の包括的倫理指 針として「ヘルシンキ宣言」を採択した。わが国に は，上卜を対象とする研究についての包括的な法律が ないため,このへルシンキ宣言に則って研究をすすめ る必要がある. ヘルシンキ宣言で述べられている倫理 的条件は以下のとおりである(4)：(1)研究の必要性, 科学的妥当性, (2) 被験者の権利と福利の保護, (3) 危害と利益のバランス, 最小限のリスク, (4)公正, (5) 被験者のインフォームド・コンセント，（6)個人 情報の保護, $(7$ ) 倫理審査委員会の承認, (8) 研究計 画の公開.

このなかで特に強調しておきたい点について以下で 述べる、まず，「医学の進歩は最終的には七トを対象 とする試験に一部依存せざるを得ない研究に基づく」 と記されている。これは，医学に関する研究を進める うえで, ヒトを用いた研究が必要不可欠であることを 述べており，今日ではバイオメカニクス研究も決して 例外ではない. 次に，「ヒトを対象とする医学研究に おいては，被験者の福利に対する配慮が科学的及び社 会的利益よりも優先されなければならない」と記され ている. 研究によって多くの成果が生まれ, 社会の進 歩に大きな貢献があったとしても, 被験者個人が不利 益を被ること，身体的・精神的に実害があることは避 けるべきである，すなわち，個人を最大限に尊重すべ きことがうかがえる。また，「研究者は，適用される 国際的法規はもとより，上卜を対象とする研究に関す る自国の倫理，法及び規制上の要請も知らなければな らない」と記されている，冒頭にも述べたが，倫理を 考えるうえでは，その背景にある文化の違い，時代変 遷を十分に考慮しなければならない，当然，国や地域 によって倫理観に違いがあることはいうまでもない. 欧米では 1960 年代から自立性尊重の考方方が国民に 広まっている。一方，わが国では，「人間は心(魂)と 体からできている」といった原日本的な考え方が残つ ている(5). したがって, 後述のように, 「欧米で行わ れている研究だから, 日本でも行ってよいだろう」と いう考え方は決して通用しないのである。

\section{4. 倫理審査委員会について}

ヘルシンキ宣言で倫理審査委員会による審査の必要 性が明記されているが,これは相互審査の原則(専門
職によってのみ審查や判定を行うのではなく, 性別, 人権, 専門を超えたさまざまな者が相互に審査や判定 を行うこと)に関連している. 以前は，信望のある専 門家に判断を任せるという考え方が主流であった。し かし, 時代の流れや権利意識の向上から, 医師・科学 者・法学者などの専門家が各自の倫理性のもとに判断 を下しても，それが一般市民や社会から一概には受け 入れられなくなってきた(5). したがって, 倫理審查委 員会は現代社会において研究の信頼性・倫理性を確保 し,さらに透明性を明確にするうえでも必要である。 わが国で現在公布されているヒトに関係する行政指針 のすべてが，一部匿名化されている試料の取扱いを除 き, 倫理審査委員会による審査を条件としている.

倫理審査委員会の目的は, 当該研究計画の倫理性, 科学的妥当性について審査することおよび被験者や 試料提供者の人権を保護することである. 研究の倫理 性が厳しく問われる現代では, 情報公開によって信頼 を得ることが求められる.したがって, 研究の承認は, 工学・医学領域だけでなく一般社会に影響を及ほすこ とがあり，もって信頼性が確保された審査手続きが必 要である.「臨床研究に関する倫理指針」(2003 年 7 月, 厚生労働省)のなかで, 倫理審查委員会についての 具体的な記載がある(4).すなわち，

（1）倫理的・科学的観点から当該研究を審査し, 文章で意見を述べる。

（2）学術的・多元的な視点からさまざまな立場か らの委員によって公正かつ中立な審査を行う。特に， 委員は自然科学の有識者, 人文科学の有識者, 一般市 民, 外部委員, 男女両性で構成されること.

（3）委員には在任中および退任後も守秘義務があ る.

（4）当該研究についての調査を行うことができ る.

各研究機関が,このような倫理審査委員会を設置し, 研究者が研究計画書を提出し, そして審査結果に従っ て研究を遂行すれば, 多くの倫理的問題は解消される はずである.しかし，わが国のすべての研究施設で倫 理審査委員会が理想的に運営されているわけではな い. 白井ら ${ }^{(6)}$ の調査によると, 医科大学・総合大学医 学部ではすべての施設に倫理審査委員会が設置されて いるのに対して, 医学に関する研究所では $53.6 \%$ しか 設置されていなかった。バイオメカニクス研究は大学 の工学系研究科や企業の研究所などでも行われている ため,これらの機関に抢ける倫理審査委員会の設置は 最低限の課題と思われる。 また, 倫理審査委員会が設 置されている機関でも, 十分な予算措置が講じられて 
いない, 外部委員の選定が曖昧である, 審査委員が十 分な知識を備えていない, などの問題点があり，これ らに対するインフラ整備が必要であると指摘されてい る(6).したがって，国の指針に従った，正当性かつ客 観性のある倫理審查委員会の設置および運営が必要で ある.そして, バイオメカニクス研究の推進のために は諸機関の取組みはもちろんのこと, 学会によるバッ クアップも必要であろう.

\section{5. いわゆる死体実験について}

欧米では, 死体(PMHS) 実験と称して, 死体そのも のを用いた生体力学的研究が行われている. バイオメ カニクス研究の進歩においてはヒ卜死体あるいはヒ卜 由来試料の使用はやむを得ないと思われるが, 少なく とも，使用においては国民の理解を得る必要がある. 前述のように，国や地域ごとに異なる文化があるゅえ， 背景にある歷史的経緯や宗教観を考慮する必要があ る. 当然のことながら，「死」や「遺体」に対する考 え方や扱いもさまざまである，最もポピュラーな例と

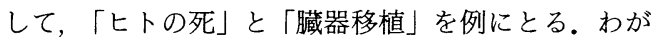
国では, 1997 年に制定された「臟器の移植に関する法 律」によって, 臟器移植を前提とした場合に限り, 脳 死がヒトの死として認められるようになった ${ }^{(4)}$.すな わち, 米国では脳死は「ヒトの死」として広く受け入 れられているが，わが国では一般の死の定義としては 認められていないのである。さらにわが国では，遺志 による臟器提供が少ないため, 移植医療も米国に比べ て少ない，その背景には，「死」や「死体」に対する 国民の考え方の違いがある。某企業の米国人社員 (米 国支社)を対象にしたアンケート調查によると疍(8), 「遺骨に死者の霊魂はあるか」という問いに対して, $87.5 \%$ のが否定しており,また, 「葬儀の際, 遺体 は完全な形が必要か」の問いに対して, $90 \%$ の人が否 定的な回答をしている.さらに，「死後，自分の体を 医学研究に供するか」という問いには, $56.1 \%$ のが 「In flavor」と回答し，また, 生存下・脳死下・心臟死 下のいずれかでの臟器提供には $95.1 \%$ の人が容認し ている．このように，米国人は遺体に対する執着は少 なく，さらに現実主義的な考えをもっているゆえ，臓 器提供の推進に結びついていると思われる。一方, 2002 年にわが国で行われた臟器移植に関する世論調 查によると(内閣府), 自分が心臟死の状態になったと き, 臟器を提供する意思があるかという問いに対して, 肯定意見は $35.7 \%$, 否定意見は $33.5 \%$ ありり, 同様 に, 脳死判定された場合の藏器提供について, 肯定意 見は $36.0 \%$ ，否定意見は $31.8 \%$ であった ${ }^{(9)}$.このよ
うに，国民の考え方に違いがあることは，科学研究を 行ううえでも十分把握していなければならない。ま た，わが国では，死体あるいは死体の一部を用いる研 究を行う際に, 知っておかなければならない法律があ るが,これについては, 次章で紹介する。

\section{6. ヒト由来組織を対象とした研究について}

ヒトの組織は, 移植医療, 医薬品の製造および試験, 医学研究，医学教育などに利用されることがある。特 に研究利用のみを考えた場合, 組織の採取源は手術に よって摘出されたもの, 病理検査・診断用に採取され たもの，解剖時に採取されたものなどがある。そして わが国では，これら組織の利用を規制する以下の法律 やガイドラインがあり,これらに則って研究が進めら れなければならない：「ヒトに関するクローン技術等 の規制に関する法律」(2000 年), 「特定胚の取り扱い に関する指針」(2001 年, 文部科学省),「ヒトゲノ 么・遺伝子解析研究に関する倫理指針」(2001 年, 文 部科学省・厚生労働省・経済産業省)，「遺伝子治療 臨床研究に関する指針」(2002 年, 文部科学省・厚生 労㗢省), 「疫学研究に関する倫理指針」(2002 年, 文 部科学省・厚生労働省), 「臨床研究に関する倫理指 針」(2003 年, 厚生労働省)。本稿では, 個々の指針に ついての具体的解説梳省略するが, いずれも条文の策 定おいてへルシンキ宣言が礎となっており，根本的原 則は変わらない。研究試料は七トに由来するゆえ, 尊 厳をもって取扱われる必要があり, 決して無断採取が

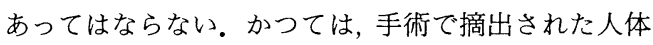
の一部は患者にとって不要であるから，「いらないか ら適正に処分して欲しい」という患者の暗鵠の了解が あると考えて処理されていた。しかしこれは，どのよ うな研究に使用されても構わないということではな い. 提供者のインフォームド・コンセントは欠かすこ とができないのである.

さて，上卜死体由来の試料取扱いを考えるうえでは， 前章のほかに遵守すべき重要な法律がある。1949 年 に制定された「死体解剖保存法」および 1983 年に制 定された「医学及び歯学の教育のための献体に関する 法律」である(10). 前者では, 医学系大学や主要病院に おいて, 医学の教育または研究のために必要があると き，遺族の承諾を得て解剖を行い，一部は標本として 保存できることが記されている，当然, 解剖を行う者 についても規定されており，また，死者の取扱いにあ たっては, 特に礼意を失わないように注意しなければ ならないとされている。あわせて同法では, 死体の一 部を標本として保存することが認められながらも，遺 
族から引き渡し要求があったときには，返却しなけれ ばならない旨が記されている。その目的は，「医学の 研究のために特に必要があるとき」と, 明確にされて いるが，人体試料がバイオメカニクス研究に用いられ ることは法の想定外であっただろう。したがって, 標 本以外の目的として使用される際には, 改めて遺族の 同意を得るか，それがどうしても不可能な場合は施設 内倫理審査委員会の承認を得る必要がある. なお, こ れについては, 死体解剖保存法のもとに行われる病理 解剖についての「病理解剖指針について」(1988 年) でも明記されている(10).すなわち同指針では，「標本 が医学の教育又は研究の用に供されなくなったとき， 又は, 遺族からの引き渡しの要求があったときは, 遅 滞なく引き渡さなければならない」, さらに，「標本 を標本としての目的以外に使用しようとするときは， 改めて遺族の同意を得なければならない」と記されて いる.

献体に関する法律についてであるが,「医学及び歯 学の教育の向上に資すること」が目的とされている. 献体者の生前における意思によって, 死後にその体が 解剖体として供されることになる。ここで, 献体者の 意思とは，「自己の身体を死後医学又は歯学の教育と して行われる身体の正常な構造を明らかにするための 解剖の解剖体として提供すること」と記されている. したがって, 当然のことながら, この法律においては, 解剖体の一部がバイオメカニクス研究に利用されるこ とは想定しておらず，また，献体者もそれを念頭にお いてはいない.したがって, 前記同様, 生前に献体者 に十分な説明を行い, 解剖体の一部がバイオメカニク ス研究に利用されることについて理解および同意を得 ることが原則である．決して，崇高な意思のもとに供 された解剖体の一部が, 安易にバイオメカニクス研究 に流用されてはならない。

\section{7. トラブルを回避するために}

これまで述べてきたように，生前あるいは死亡した あとに人体から摘出された臓器や組織は, 貴重な試料 として利用されてきた。すなわち, 医療・研究・教育 の目的で利用され，直接および間接的に国民の健康維 持に用られてきた，前章までに述べたように，研究者 が人体由来の臟器や組織等を用いる場合に, その使用 目的, 試料の採取方法, 採取されたあとの取扱いに十 分配慮しなければならない.これを急ることは，倫理 的に許容されないばかりか,さまざまなトラブルに結 びつく。森 ${ }^{(11)}$ は, ヒト由来試料の利用に問題がある として訴訟に発展した例あるいは立件されなかったが
社会的論議をよんだ例を解析し，その原因別に以下の ように分類した。すなわち，

（1）医療・研究・教育に利用することが科学的に 妥当かどうかが問題にされた例.

（2）提供者である患者あるいは遺族の同意なしに 利用されたことが問題になった例.

（3）礼節が問題になった例.

（4）試料の供給をめぐる金銭のやりとりが問題に なった例.

である。（1）については, 研究の妥当性を施設内倫理 委員会で審査することになっているため, 今後, この ようなトラブルは減少すると思われる，また，(2)〜 （4）については，研究者が遵守すべき基本的かつ最低 条件であり, 本稿での議論は無用と考えるが, 学生ま でにおける倫理・教養教育によってクリアされると信 じている.

さて，上記のようなトラブルを回避するためにも， 倫理的に正当な手続きを踏む必要がある. ヒト由来試 料の取扱いにおいては, ヘルシンキ宣言に則り，提供 者の意思が最大限に尊重されなければならない. 近 年, 前述のような正しい手続きを踏んだうえでの研究 資料入手が困難であるため, 外国のヒト組織・臓器を 商品として購入する行為が散見される。これらは, 研 究利用について, 提供者の同意が得られているもので ある.しかし，前章で述べたように，海外とわが国で は国民の倫理観や価值観が異なる。さらに，わが国に おける研究の将来発展を考えた場合，このような商品 の利用は一時的な解決であって, 根本的な解決ではな い. したがって, 研究のためのヒト由来組織の採取・ 利用についての包括的対策を考え，立法化することも 課題であろう.

\section{8. 疫学研究について}

疫学研究は, 健康に関する事象の頻度や分布を調查 し，その要因を明らかにする科学研究である. 読者の なかには, 事故の分析や器具の有効性を判断するうえ で, 疫学研究に携わる方もおられるだろう. 疫学研究 では，対象者のプライバシーに配慮することが求めら れてきたが,ささらに, 個人情報保護の世論が高まった ことで，一層の配慮が求められるようになった。 2003 年 5 月に個人情報の保護に関する法律 (個人情報保護 法)が公布された.しかし，同法第 50 条では，学術研 究は法の適用外と明記されている。そのうえで，「個 人情報の適正な取扱いを確保するために必要な措置を 自ら講じ，かつ，当該措置の内容を公表するように努 めなければならない」とされている，すなわち，研究 
者は対象者の心身の状態や周囲の環境, 生活習慣等に 関する具体的な個人情報を取扱うことがあるため, 疫 学研究に関する倫理指針にそって研究を進めなければ ならない.このなかで, 研究の科学的合理性と倫理的 妥当性を確保し, 個人情報を保護し, インフォーム ド・コンセントを受けて研究を行い, 研究成果を社会 に公表すべきことが示されている．詳細な規定がある が, 本稿では省略する.

\section{9. 研究者に望むこと}

以上, バイオメカニクス研究を遂行するうえでの倫 理的配慮の必要性, さらにはヒトおよびヒト由来試料 を研究対象とする際の原則について述べた。多くの研 究者は, これら原則や指針に則って正当な研究を進め ていると思われる。しかし一部で, 社会通念や倫理規 範に欠ける研究が行われていることも事実である。一 部の研究者の行為によって, バイオメカニクス研究に ついての信頼が損なわれれば, 研究が滞るだけでなく， 研究成果がもたらす恩恵を待つ人々に不利益が生じる のである，学会や研究会などの組織では, 当然のこと ながら, 発表, 講演, 論文投稿の際に倫理的配慮を確 認し, 社会的信頼の確保に努めているはずである。し かし, 個々の機関における日々の研究実態を把握する ことは困難である.したがって, 各研究機関や研究者 が自主的に倫理問題に配慮すべきであり，また，若手 研究者や学生への教育を積極的に推進するべきであろ う。「知らなかった」あるいは「教わっていなかった」 では，通用しないのである。

一般の研究者は, 倫理審査委員会の審査を受けるこ とは余分な負担と考えるかもしれない.しかし，研究 の正当性や透明性を確保することは必須事項であり， また, 研究者や研究機関が倫理的内容で糾弾されるリ スクを回避できることにもなる、今後はバイオメカニ クス研究をすすめるうえで, 倫理的側面にも十分配慮 すべきである.

\section{文献}

(1) Kato, H.: Basic problems of bioethics. Kyoiku to Igaku 50 (2002), pp. 944-950, (in Japanese).

(2) Committee of Impact biomechanics, Society of Automotive Engineers of Japan: Impact biomechanics for engineers and medical staff, Society of Automotive Engineers of Japan, Tokyo, (2006), (in Japanese).

(3) Mizuno, K., and Hitosugi, M. : Injury Biomechanics, Society of Automotive Engineers of Japan, Tokyo, (2003), (in Japanese).

(4) Editorial Committee, Data for Bioethics and Law: Data for Bioethics and Law, Taiyo Publishing, Tokyo,
(2004), (in Japanese).

(5) Matsumura, T.: Thoughts on organ donation with special references to basic rules for handling human materials without intention to utilizing them for donors' own therapy. Ishyoku 40 (2005), pp. 129-142, (in Japanese with English abstract).

(6) Shirai, Y.: The current state of Ethics Committees in Japan. SRL Houkan 28 (2004), pp. 87-91, (in Japanese).

(7) Ikeguchi, G. et al.: Characteristics of consideration for "Death" in Americans. Igaku to Seibutsugaku 150 (2006), pp. 293-296, (in Japanese).

(8) Ikeguchi, G. and Ishizu, H.: Characteristics of consideration for "Brain death" and "Organ transplantation" in Americans. Igaku to Seibutsugaku 150 (2006), pp. 372-376, (in Japanese).

(9) The Prime Minister's Office in Japan: Public opinion poll for organ transplantation. http://www8.cao.go.jp/ survey/mhlw/h14/h14-zouki/index.html (in Japanese).

(10) Editorial Committee, Basic Medical Laws in Japan: Basic Medical Laws in Japan, 2005 revision, Chuou Houki, Tokyo (2004), (in Japanese).

(11) Mori, S.: Current status and problems in the use of human tissues and organs. Igakuno Ayumi 222 (2007), pp. 93-97, (in Japanese).

(12) Ozawa, T.: Use of human tissues and organs. Igakuno Ayumi 222: 114 (2007), (in Japanese).

\section{附録}

記載した参考文献には, 英語の書名が無い物が含ま れている。 それらは執筆要綱に従って英訳して表記し たが, 読者による引用時の労を考慮して, 附録として 日本語の参考文献を以下に記す。

（1）加藤尚武: 生命と倫理の根本問題, 教育と医学 50 , (2002), pp. 944-950.

（2）自動車技術会インパクトバイオメカニクス部門委員会: 工学技術者と医療従事者のためのインパクトバイオメカ ニクス, 自動車技術会, 東京, (2006).

（3）水野幸治・一杉正仁：交通傷害バイオメカニクス，自動 車技術会, 東京, (2003).

（4）生命倫理と法編集委員会 編: 資料集 生命倫理と法, 太 陽出版, 東京, (2004).

（5）松村外志張：臟器提供に思う，移植 40，(2005)，pp. 129142.

（6）白井泰子：かが国の倫理審査委員会の現状，SRL 宝函 28, (2004), pp. 87-91.

（7）池口豪泉・永田良一・石津日出雄：“死”に関する米国人 の意識の特質, 医学と生物学 150, (2006), pp. 293-296.

（8）池口豪泉・石津日出雄：“脳死と缄器移植”に関する米国 人の意識の特質, 医学と生物学 150, (2006), pp. 372-376.

（9）内閣府：藏器移植に関する世論調査，ホームページ, http://www8.cao.go.jp/survey/mhlw/h14/h14-zouki/ index.html

（10）基本医療六法編䇣委員会編：基本医療六法平成 17 年版, 中央法規, 東京, (2004).

(11) 森茂郎：人由来試料の研究 - 教育 - 医療での利用. 医学 のあゆみ 222, (2007), pp. 93-97.

（12）小澤時男：人体試料の利用，医学のあゆみ $222 ，(2007)$, p. 114. 